\title{
Evaluation of Educational Tourism Based on Agribusiness In Community Forest Areas
}

\author{
Anang Susanto $^{1^{*}}$, Indah Rekyani Puspitawati ${ }^{2}$ \\ 1,2 Departemen of Agricultural Science, of Merdekat University, Jl.Serayu79 \\ Madiun, East of Java, Indonesia \\ * Corresponding author: \\ Email: Asmadiun@yahoo.com
}

\begin{abstract}
.
The development of educational tourism is an urgent matter; many sectors of life are automatic will play a role. Educational tourism is developing, so from an economic point of view, the community's economy will also increase. The local population, the majority of whom are farmers, is very important for playing an active role in the development of educational tourism to benefit and impact farmers to improve their welfare. This research aims to describe how the evaluation of educational tourism activities in the Madiun district. This research method is qualitative with a case study approach. The results showed that farmers participated in the development of educational tourism, starting from the planning stage to the evaluation. The success of community-based educational tourism development in Madiun Regency is inseparable from promotion and development society, both from the ecological, economic, sociocultural, and political aspects
\end{abstract}

Keywords: participation, education, ecology, economy, society

\section{INTRODUCTION}

The development of educational tourism forest by integrating agribusiness can increase community participation in forest preservation and environmental sustainability. Forests have a variety of potential, natural wealth, cultural, social, and different customs. Educational tourism is synonymous with something interesting, fun, unique and makes tourists feel comfortable, safe, and happy. Beautiful natural scenery, beautiful environment, remarkable cultural diversity, and various amusement rides are the main attractions of a tourist destination [1].. Tourist destinations are also diverse, ranging from; waterfalls, mountain climbing, beaches, lakes, lakes, and artificial tours with various amusement rides in them.

The existence of tourism has now become one of the essential needs for everyone, even families, to refresh the brain and body that is tired of working or just for entertainment with friends or family. The various educational and cultural tourism potentials of a forest and the high interest in tourism for everyone encourage people around the forest who are aware of educational tourism to develop their forests into sustainable ecotourism [2]. Educational tourism is a tourist destination that enjoys an impressive and great diversity of natural life and human culture without causing 
damage to nature. [3]. This research aims to describe how the evaluation of educational tourism activities in the Madiun district.

\section{METHODS}

\section{Study area}

This research was conducted on the slopes of Mount Wilis, precisely in Kare District, Madiun Regency. This study follows the constructivist paradigm where this study describes the impact of developing the Wilis tourist area for farmers on their fruit and vegetable picking in the field. The selection of this area is based on the following considerations: [1] Kare Tourism District is based on a participatory basis; [2] The location of the Kare sub-district is directly adjacent to the forest, and cultivated land with various types of vegetables; [3] Researchers have conducted a preliminary study of the community on the slopes of Mount Wilis so that it can be used as a starting point to explore the characteristics of farmers on the slopes of the mountain.
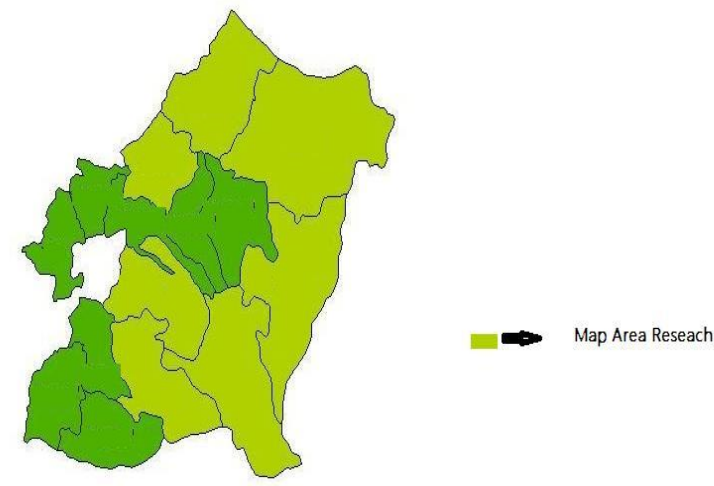

Fig 1. Study Area - Educational Tour, Madiun Distric

This study uses qualitative methods;[4], qualitative methods tend to be holistically associated with the subjective nature of social reality, so this method has an excellent ability to track the effects of assimilation. [5] , qualitative research methods are research methods that examine the state of natural objects. Natural objects are objects as they are, which are not manipulated by the researcher so that their condition remains relatively unchanged before the researcher enters the object, while in the object, and after leaving it. The research instrument is the researcher himself (human instrument) Researchers in this case as a central tool.

\section{RESULT AND DISCUSSION}

Researchers define the research focus, select informants as data sources, interpret the data and draw conclusions from their findings. This research is a case study where [6] , a case study is an empirical study that examines phenomena in a natural context and uses various sources of evidence. The data sources of this research are words and facts. The rest are additional data such as documents and others [7] . 
obtained through in-depth interviews, observation, focus group discussions, document analysis (content analysis), and observation. Not essential. The unit of research in this study is the area and focuses on developing tourist cities, so the analysis technique used is a case-by-case analysis. [8] , the analysis process is carried out with an interactive analysis model. In this analysis model, the three analysis components are data reduction, data presentation, and conclusion or verification.

The participation of farmers in the development of tourism areas. Farmers in the sub-district who are residents are the key to the sustainability of the development of educational tourism in the Kare sub-district. [9] According to Neth (2008), local communities and local authorities are vital figures in sustainable development. This means that in developing a tourism district, there must be cooperation and synergy between actors. The story of this tourist area is an implementation of the concept of a community and sustainable approach. Therefore, the Kare community-based educational tourism area can be identified as part of the approach taken in community development interventions to develop educational ecotourism. The focus of creating this educational tourism area is the community's active role as participants. The proof is that the people of Kare district know better and are more familiar with nature and culture, which are the potential and selling points of educational tourism, so that community participation, according to fig 1 , is necessary. The following are the stages of community participation in the development of Kare Regency Educational Tourism:

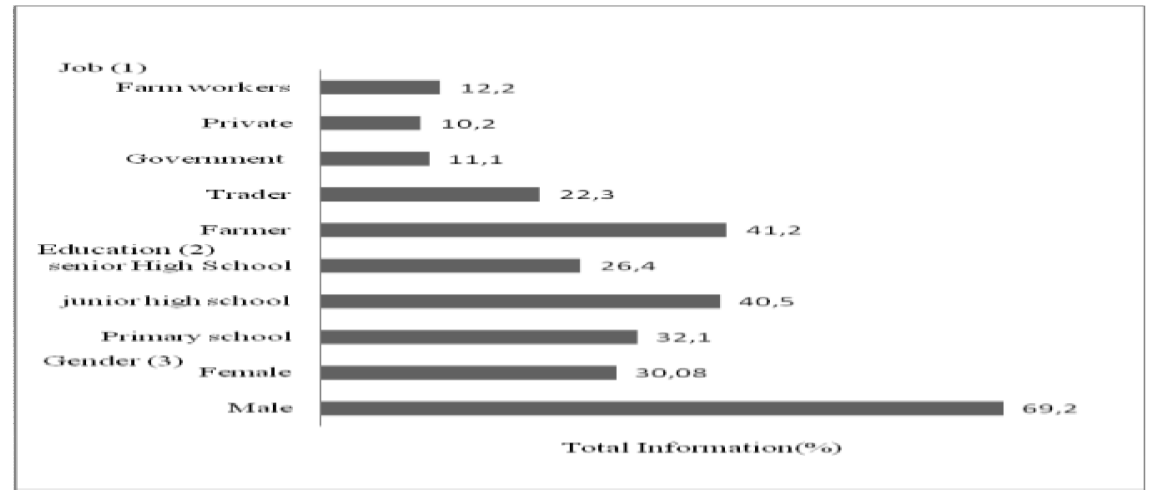

Fig 2. Demographics farmers in Madiun Regency

Table 1. Farmers' Participation in Educational Tourism Development

\begin{tabular}{|c|c|c|}
\hline $\begin{array}{l}\text { Community } \\
\text { Activities }\end{array}$ & It is already done & Necessary \\
\hline Planning & $\begin{array}{l}\text { a. Farmers are involved in } \\
\text { planning the development of } \\
\text { educational tourism to obtain } \\
\text { information about opportunities } \\
\text { that can be developed } \\
\text { b. Farmers getong royong } \\
\text { cleaning the location for tourist } \\
\text { sites } \\
\text { c. Farmers give their all the food }\end{array}$ & $\begin{array}{l}\text { a Farmers should follow a } \\
\text { routine in identifying } \\
\text { problems with various } \\
\text { participatory } \\
\text { pproaches, for example, } \\
\text { PRA, FGD, and others } \\
\text { b. Farmers should take part } \\
\text { actively contribute ideas } \\
\text { or feedback regarding }\end{array}$ \\
\hline
\end{tabular}




\begin{tabular}{|c|c|c|}
\hline & $\begin{array}{l}\text { they have in meeting or } \\
\text { meeting to discuss planning }\end{array}$ & $\begin{array}{l}\text { tourism development } \\
\text { c. Farmers should be } \\
\text { involved inrelated } \\
\text { decision making }\end{array}$ \\
\hline Activity & $\begin{array}{l}\text { a. Farmers around tourist sites } \\
\text { involved in site revitalization } \\
\text { for making photo spots } \\
\text { b. Farmers participate for } \\
\text { keep the environment } \\
\text { clean tourist sites }\end{array}$ & 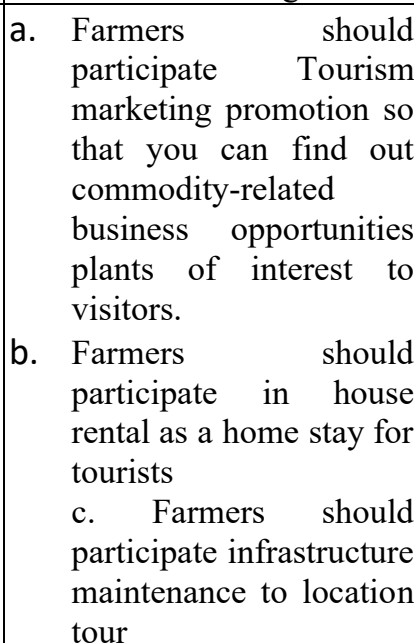 \\
\hline yield utilization & $\begin{array}{l}\text { a. Farmer can sometimes sell } \\
\text { vegetable to visitors who cross } \\
\text { the road go to tourist sites } \\
\text { b. Vegetable farmers can leave } \\
\text { their productsthe money is } \\
\text { deposited in stalls in village } \\
\text { locations tour } \\
\text { c. Even though it's a small } \\
\text { amount, some visitors } \\
\text { sometimes come pick } \\
\text { vegetables directly and buy } \\
\text { them. }\end{array}$ & 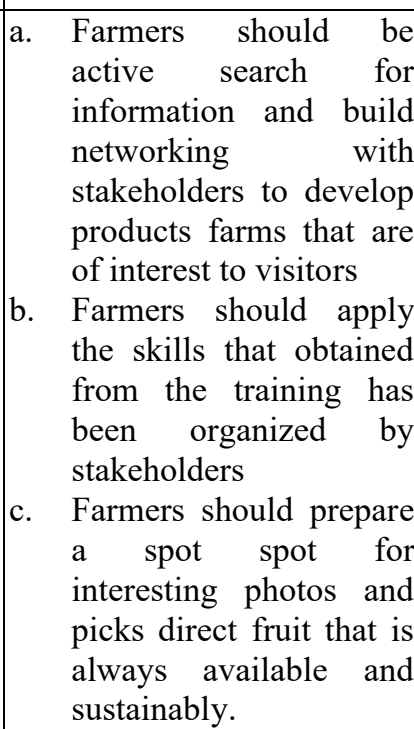 \\
\hline evaluation & $\begin{array}{l}\text { Farmers come to see and } \\
\text { supervising tourism development } \\
\text { through farmer groups }\end{array}$ & $\begin{array}{ll}\text { a. } & \text { Farmers should come } \\
& \text { right away provide } \\
& \text { criticism and } \\
& \text { suggestions to good tour } \\
& \text { manager requested or } \\
\text { not } & \\
\text { b. } & \begin{array}{l}\text { Farmers should com } \\
\text { provide development }\end{array} \\
\text { solutions directly to the } \\
\text { tour manager }\end{array}$ \\
\hline
\end{tabular}

Source: Primary Data Analysis through in-depth interviews 2020 
In general, the participation of fruit and vegetable farmers is involved from planning to evaluation, but at a low level. The low participation of farmers is due to this; (1) Due to the gap in education and experience, most farmers who are close to educational tourism objects generally have an elementary school diploma and are relatively older, so it isn't very easy; (2) economically, farmers in educational tourism areas are pretty rich, which makes them feel that they have lived long enough to be less interested in doing something extraordinary; and (3) the absence of a joint forum that can become a forum for all levels of society to develop their skills. Farmer participation means [10] that community participation is based on the power of the community to determine the final product. Conceptually, participation in strategy implementation is achieved by involving:communities in exchanging information, setting goals, setting guidelines, allocating resources and financing sources, implementing programs, and distributing them, by communities benefit from planning to implementation. Fair results. To include. Several things must be done through external intervention to achieve these goals, as long as the external intervention does not harm the local population.

\section{Eevaluation for the Development of Educational Tourism in Kare Regency}

This is following [11] stated that the most effective intervention in community development was in the form of group activities and most of the ineffective interventions received individual social support. Group interventions were rated as effective interventions less frequently than individual interventions. The categories are social agent interventions, psychotherapy, health and social care delivery, referral interventions, and skills development/recreation. The impact of the development of the Kare tourism sub-district that is felt by the local population makes this tourism subdistrict an example of a reference in the development of the tourism sub-district. Many visitors from various sub-districts came to visit and intend to conduct comparative studies. This is in line with research [12], that the implications of managing ecotourism areas in Indonesia have a positive impact, causing improvements in various aspects, including service, culture, arts, trade, and skills.

Table 2. Evaluation of the development of educational tourism for farmers

\begin{tabular}{|l|l|l|}
\hline Impact aspect & \multicolumn{1}{|c|}{ Description } & \multicolumn{1}{|l|}{ Implication } \\
\hline Aspect & $\begin{array}{l}\text { a.Tourism development done } \\
\text { collaboratively cooperation between } \\
\text { all citizens } \\
\text { b.Local arts and culture on display in } \\
\text { every certain moment e.g. birthday } \\
\text { etc. }\end{array}$ & $\begin{array}{l}\text { Strengthening of social } \\
\text { capital values to the } \\
\text { local community } \\
\text { Preservation of local } \\
\text { culture } \\
\text { Provide assistance for } \\
\text { People who own a } \\
\text { business productive } \\
\text { economy }\end{array}$ \\
\hline Economic Aspect & - There are additional commodities \\
\hline
\end{tabular}




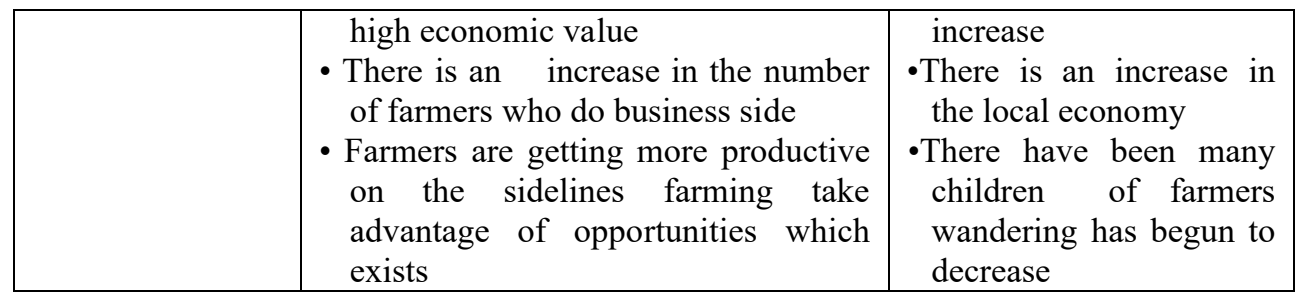

Source: Primary Data Analysis through in-depth interviews 2020

The development of ecotourism areas has also given rise to food vendors, transportation services, restaurants, accommodation services, and food stalls. This is also in line with [13] research that ecotourism has many benefits, especially for the economy of remote areas. Ecotourism helps support the diversification of livelihoods in the area. Ecotourism has shallow barriers to market entry and has the potential to thrive even with an unspecified workforce. Promoting local livelihoods through ecotourism is seen as an essential policy tool for biodiversity conservation. The objectives of ecotourism are to increase economic growth, social emancipation, preservation of natural resources, and improve livelihood activities. According to [14], social benefits can also be increased through appreciation and understanding between cultures between the host community and visitors.

\section{CONCLUSION}

The development of the Kare Tourism District implements the concept of a sustainable and community-based development approach. It has been proven that the development of the Kare tourism area can positively impact vegetable farmers around the Kare tourism site, both in terms of socio-cultural and economic. The success of community development in the Kare Tourism Regency cannot be separated from community development interventions, both in terms of ecology, economy, socioculture, and politics

\section{REFERENCES}

[1] Marpaung, H. 2002. Pengetahuan Kepariwisataan Edisi Revisi. Bandung : Alfa Beta. Nuryanti, Wiendu. 1993. Concept, Perspective and Challenges, makalah bagian dari Laporan Konferensi Internasional mengenai Pariwisata Budaya. Yogyakarta: Gadjah Mada University Press. Hal. 2-3

[2] Suwantoro, Gamal, 1997. Dasar-dasar Pariwisata. ANDY. Yogyakarta.

[3] Hari Hermawan, 2016. Dampak Pengembangan Desa Wisata Nglanggeran terhadap Ekonomi Masyarakat Lokal. Jurnal Pariwisata Vol III, No. 2.pp

[4] Daymon, Christine dan Holloway, Immy. (2008). Metode Riset Kualitatif dalam Public Relations dan Marketing Communications. Yogyakarta: Penerbit Bentang.

[5] Sugiono. (2013). Memahami Penelitian Kualitatif. Bandung: Alfabeta.

[6] Yin, Robert.K. (1987). Case Study Research : Design and Methods. Beverly Hills. California : Sage Publication. 
[7] Sutopo, (2002). Metodologi Penelitian Kualitatif: Dasar Teori dan Terapannya dalam Penelitian. Surakarta : Sebelas Maret University.

[8] Miles, Matthew. B dan Huberman, A. Michael, (1992). Analisis Data Kualitatif. (Terj. Tjetjep Rohendi Rohidi). Jakarta : Universitas Indonesia.

[9] Neth, Baromey. (2008). Ecoutourism as a Tool for Sustainable Rural Community Development and Natural Resources Management in the Tonle Sap Biosphere Reserve. University of Kassel. 3-232

[10] Riristutingisia, D, Wahyunadi, Iwan H. 2017. Public Participation in Rural Development Planning. Economic and Development Journal. 9 (1) : 57- 65..

[11] Gardiner, C., Gideon, G., Meryn, G. (2016). Interventions to reduce social isolation and loneliness among older people: an integrative review. Health an Social Care. 1-11

[12] Baskoro MSP. (2016). Pengelolaan Kawasan Ekowisata Berbasis Masyarakat Serta Implikasinya Terhadap Ketahanan Masyarakat Desa Sukarara. JJG Journal Green Growth dan Manajemen Lingkungan. Vol 5(2): 18-29

[13] Riasi, A., \& Pourmiri, S. (2015). Effects of online marketing on Iranian ecotourism

[14] Sangpikul, A. (2017). Ecotourism Impact on The Economy, Society, and Environment of Thailand. Journal of Reviews on Global Economic. Vol 6(1): 302-312 